History

Education

Research

Journal
Körber, A. (2018) 'Transcultural history education and competence: Emergence of a concept in German history education'. History Education Research Journal, 15 (2): 276-91. DOI https://doi.org/10.18546/HERJ.15.2.09

\title{
Transcultural history education and competence: Emergence of a concept in German history education
}

\author{
Andreas Körber* - University of Hamburg, Germany
}

\begin{abstract}
In most Western countries, traditional history education has been challenged by criticism of the underlying national framework, and by processes of globalization and immigration. In Germany, as a consequence, concepts of intercultural relations, (the interpersonal dynamics between people from different cultures) have been explored since the 1990s. This article outlines the development of these concepts in relation to criticism of theories of culture, the challenges of coming to terms with the specific German past, and the recent stages in the conceptualization of intercultural historical competences. Against this backdrop, multicultural profiling, which describes the characteristics of different cultures, is applied to one of the central principles of German history education, multiperspectivity.
\end{abstract}

Keywords: Germany; historical competence; intercultural education; history education; multicultural education; multiperspectivity; PISA; competence-based education

\section{Introduction}

Being fundamentally nationalistic by tradition, history education faces specific challenges in post-traditional, post-migrant societies, in which neither subjects nor learners can be simply categorized into groups of 'we', 'you' and 'them' along national or cultural lines. Immigrants' attitudes and ways of relating to the negative aspects of German history, National Socialism and the Holocaust have been researched (Georgi, 2003), and also the attitudes of student history teachers. A broad spectrum of views was found. Other post-migrant societies no longer taking a traditional, national view of history also have to address sensitive and problematic complexities of European history. For example, in teaching about colonial rule and the Crusades, how can immigrants, especially those with ancestors on the other side of these conflicts, accept and critically address the problematic past(s) of their new homes, making it part of their own history? How can inter- or transcultural history education be conceptualized so that it also addresses and acknowledges members of European societies with origins outside Europe? Clearly, the traditional concepts of 'us' and 'them' - today and in the past - will not work in these cases.

\section{From monoculture to intercultural history education: A conceptual development}

Within an uncompleted process of pedagogical modernization of general and history education in Germany, intercultural history education marks both a 
dimension and a phase. In its early stages, this general process moves from a topicand knowledge-centred form of teaching, to presenting students with a revised and multifactorial, but still national, master narrative, generally told by teachers or presented by authoritative texts in books. Later on, students were to develop their historical consciousness (for example, Jeismann, 1977; Rüsen, 2005), and later their competences of historical thinking (Barricelli et al., 2012) by actively engaging with primary sources (Lucas, 1985; Becher, 1985) and addressing societal concerns, such as gender, environmental history, and also the Holocaust. The national master narrative was further broadened by introducing the perspectives of different social groups, and of people with different cultural and ethnic backgrounds. More recently, strategies are being developed to ensure that all students can participate in reflective history education, whatever their different learning needs (see, for example, Alavi and Lücke, 2016; Körber, forthcoming, 2019; Körber et al., forthcoming, 2019; Bormuth et al., forthcoming, 2019).

In the beginning, this process of developing increasingly inclusive history education drew on early attempts from the inter-war period and the 1950s (Kawerau, 1924; cf. Tiemann, 1979; Hasberg, 2002) to reform history textbooks by organizing bilateral commissions and conferences of historians from Germany and countries that it had invaded (France, Poland), and later also Israel (cf. Ruchniewicz, 2005). Then, the active German recruitment of foreign guest-workers (1960 to 1973) triggered a slow development of sensitivity to cultural diversity in pedagogy (Nohl, 2010). Initial ideas of preparing the guest-workers' children for returning to their home countries were soon replaced by an attempt, however feeble, to integrate them into German society. Nevertheless, well into the 1990s, teaching remained mainly within a national framework, depicting guest-workers as 'the others' (Höhne et al., 1999: 42).

The concept of cultural diversity was gaining prominence by the end of the 1990s. This was largely due to Alavi's dissertation on 'history education in an ethnically plural society' (Alavi, 1998), drawing extensively on Schörken's concept of Fremdverstehen (intercultural understanding). The concept of cultural diversity existed as early as 1980 (Schörken, 1980), and the concept of multiperspectivity was introduced by Klaus Bergmann $(1994,2004)$ and others. Alavi's (1998) approach was clearly based on concepts of multi- and intercultural societies, and marked a milestone in recognizing that history education could play a central role in enabling society to address the new situation of increased cultural diversity. This is fully in line with Jörn Rüsen's $(1983,2005)$ theory that learning in history is mainly about making connections between the past, the present and the future, not just learning about the past.

In 2001, a book on intercultural history education explored ways in which cultural differences could enhance teaching and learning, at theoretical and practical levels (Körber, 2001a). For example, Bodo von Borries (2001) considered six topics in which this might be done: (1) contacts and conflicts of cultures; (2) understanding the 'other'; (3) migration and minorities; (4) multicultural societies; (5) human rights; and (6) generating and changing identities. Körber identified three approaches to teaching history in which the intercultural dimension is represented: (1) it is integral to the topics to be addressed; (2) the primary and secondary sources, accounts and recounts used to teach a topic are selected from at least two, or ideally from several, cultures; and (3) learners from different cultures work on the same subjects (for example, by email or in online projects). Such an approach involves a multiperspectival view, not only of the past, but also of present concerns. (Körber, 2001b, 2017b).

On this basis, for a few years, intercultural history education flourished, specifically with a focus on migrants addressing their identities between and across societies 
and cultures (Meyer-Hamme, 2009; Georgi and Ohliger, 2009). After opening up opportunities for diverse social perspectives in the 1970s and 1980s, and for students to make connections between the past, the present and the future, intercultural history teaching had achieved the second step in innovating new content and different perspectives in German history teaching. The aim was for the different perspectives and interpretations of first- and second-generation immigrants to be accepted.

At this stage, innovations in history education to broaden such perspectives slowed down. This was because in 2000 German secondary education, which previously had been highly regarded, was ranked below average among the countries participating in the Programme for International Student Assessment (PISA). This led to reforms, which focused on outcomes and accountability, rather than on enhanced inclusion. For history education, however, it also meant a new phase of further innovation, namely the development of competences in historical thinking (Körber et al., 2007; Barricelli et al., 2012; cf. Körber, 2015), which could be related to intercultural history education.

\section{From intercultural history education to the development of transcultural historical competence}

\section{Intercultural history education}

The concept of intercultural historical competences was developed in three stages. The first proposal (Körber, 2001b) focused on the concept of cultures, and was different from later developments. It identified three key elements: cognitive aspects, emotional aspects and complex skills. By cognitive elements, Körber (ibid.) meant knowledge of individual cultures, and of the similarities and differences between them. This requires awareness of one's own culture, its values and cultural standards, and those of other cultures, which are not necessarily equivalent. It requires awareness of the limits of one's own understanding, an appreciation of both closeness and respectful distance between cultures (Ulich, 2000), and a willingness to change one's perspectives. It involves knowledge of the historical relationships between peoples with different cultures, and particularly knowledge of historical inequalities and asymmetries of power.

Emotional or affective elements depend on being open to learning about other cultures and being curious about them (Ulich, 2000), and on a willingness to integrate foreign cultures into one's own. This includes not being unduly fearful of threats, and a determination to avoid stereotyping or assuming superiority. It also requires tolerance of aspects of other cultures if they seem strange. Complex skills include bringing together and harmonizing aspects of different cultures, and the ability to behave appropriately in another cultural setting. This requires a sensitivity towards the impact of past and present experiences on members of other cultures (Ulich, 2000). At the highest level, complex skills depend on a sound knowledge and understanding of other cultures, as set out below (Thomas, 1993).

Intercultural historical competence, after Körber, 2001 b (cf. Körber, 2017b)

Cognitive elements:

- knowledge of cultural differences and individual cultures

- basic knowledge of the history of relations between peoples and cultures, especially with regard to historical inequalities, reservations, asymmetries of power

- awareness of cultural differences and similarities 
- perception of one's own cultural awareness minted in values, interpretative patterns, cultural standards

- perception of foreign 'cultural standards' as alternatives (not necessarily equivalent)

- perception of the limits of one's own understanding: ability to 'understand proximity' as well as to maintain 'respectful distance' (Ulich, 2000)

- ability to adopt other perspectives.

Emotional/affective elements:

- a cultural openness and curiosity (Ulich, 2000)

- a lack (or at least a civilizing) of fears of threats, of will to superiority and stereotyping

- an appreciation of cultural peculiarities, tolerance, solidarity.

More complex skills:

- the ability to coordinate culturally divergent action schemes

- the ability to integrate foreign standards of acting into one's own, and to act successfully within the different culture

- a sensitivity to various forms of ethnocentrism and discrimination, and to the impact of past and present experiences with member of other cultures (Ulich, 2000)

- finally (as the highest level) a 'general ability of cultural learning and cultural understanding', of quick orientation in foreign cultures (Thomas, 1993: 382).

\section{Transcultural history education}

But these categories were challenged. Wolfgang Welsch (1999), addressing the problematic assumptions of both multi- and intercultural philosophies, developed the concept of transculturalism. Transculturalism no longer regards culture(s) as homogeneous and mutually exclusive entities, but rather as mental complexes to which human beings refer when conceptualizing their identities in the multidimensional space of what they share and of what differences separate them (for a critique of Welsch, 1999, cf. Ullrich, 2016: 169ff.). Culture, then, being a construct that is complex and multifactorial, not homogeneous and not discrete, interlinks, rather than divides, individuals from different groups. Rathje $(2006,2007)$ postulated that culture was more about cohesion in the light of differences than about coherence between an individual and a group. Therefore, intercultural learning is not about acquiring knowledge of other cultures, but rather about gaining insight into the internal difference of cultures, their lack of homogeneity, and also their commonalities. It is about constructing cultural connections across cultural divides, and thus reducing, but not eliminating, diversity and foreignness.

\section{Transcultural competency: Focused history education}

This theoretical development allowed the concept of intercultural history education to progress towards a competency-focused and transcultural understanding, which could address intercultural tension and even conflict. Transcultural understanding implies that cultures are multiple and dynamic, and accepting that there are different cultures within a society, while recognizing that cultures are also powerful dimensions of personal, familial and collective identities. 
On this basis, Körber and Meyer-Hamme (2008; cf. Körber, 2015: 21ff.) suggested that intercultural historical learning should be characterized as an elaboration of the competences of historical thinking. Learners need to: (1) master conventional societal concepts, in identifying themselves and distinguishing their own history from the histories of others, which involves national perspectives; and (2) be able to override these differences by critically reflecting on concepts of cultures and cultural standards, identities and identity-based claims. This competence was outlined in three levels (see Table 1; cf. Körber, 2015: 40-1).

\section{Table 1: Levels of intercultural historical competence}

\begin{tabular}{|c|c|c|}
\hline $\begin{array}{l}\text { Traditional } \\
\text { understanding } \\
\text { of (inter-)cultural } \\
\text { learning }\end{array}$ & \multicolumn{2}{|c|}{ Levels of intercultural competence } \\
\hline $\begin{array}{l}\text { Unquestioned, } \\
\text { unreflective, } \\
\text { natural rootedness } \\
\text { in one's own } \\
\text { culture }\end{array}$ & Basic & $\begin{array}{l}\text { - Inability to consistently refer to concepts } \\
\text { of culture and differences used in society. } \\
\text { - A non-reflective and even unconscious } \\
\text { sense that belonging to one's own culture } \\
\text { is an unquestionable fact. }\end{array}$ \\
\hline $\begin{array}{l}\text { Categorical } \\
\text { understanding } \\
\text { of differences } \\
\text { between one's } \\
\text { own and other } \\
\text { cultures }\end{array}$ & $\begin{array}{l}\text { Intermediate/ } \\
\text { conventional }\end{array}$ & $\begin{array}{l}\text { Development of: } \\
\text { - } \quad \text { a concept of culture as defining groups of } \\
\text { people } \\
\text { - recognizing categories of differences } \\
\text { - the ability to understand their distinctive } \\
\text { function. }\end{array}$ \\
\hline $\begin{array}{l}\text { Understanding } \\
\text { differences } \\
\text { between cultures }\end{array}$ & & $\begin{array}{l}\text { Ability to refer to and apply the conventional } \\
\text { concepts of culture(s) and differentiating } \\
\text { criteria for reasoning about one's belonging } \\
\text { to a group (culture), and also to question } \\
\text { it, criticizing claims of affiliation, and to } \\
\text { recognize that some attitudes and customs } \\
\text { of different groups may be combined } \\
\text { ('bi'-cultural etc.). }\end{array}$ \\
\hline $\begin{array}{l}\text { Ability to } \\
\text { switch cultural } \\
\text { perspectives/to } \\
\text { think like members } \\
\text { of other cultures }\end{array}$ & Elaborate/reflective & $\begin{array}{l}\text { Ability to: } \\
\text { - understand that all cultures are social } \\
\text { constructs, and the function and limits of } \\
\text { such concepts } \\
\text { - to accept differences within, and } \\
\text { commonalities across, cultures } \\
\text { - to reflect on the combination of aspects } \\
\text { of different cultures being combined } \\
\text { - to reflect on and reconstruct cultural } \\
\text { identities. }\end{array}$ \\
\hline
\end{tabular}

Source: Körber and Meyer-Hamme (2008: 325-6)

Next, Körber (2010) suggested conceptualizing history and culture as two intersecting dimensions of individual orientation. Similar to temporal meaning being constructed by using different narrative patterns, concepts of culture are applied in order to situate the individual and collective self within the larger social group. Culture, then, is a mental tool for making sense of the tension between two insights - that we are all different and that individuals share some traits with others, but not with all. Facing this 
tension provides a range of concepts for grouping people together, and for identifying oneself with some, but not with others. Cultural competence is defined by the ability to acquire these concepts, to understand their function, and to be able to reflect on this process.

Such concepts of culture and ethnicity, but also of multi-, inter- and transculturalism, are not only a conceptual basis for intercultural learning, but also an aspect of it. Students must acquire these concepts as different ways of thinking about homogeneity and diversity, in order to structure their world (Körber, 2010: 33ff.).

\section{Two directions of intercultural historical sense-making}

Intercultural historical thinking involves reflecting on two intersecting dimensions: continuity, and changes in cultural homogeneity and diversity across time (see Table 2). This is a constant in the study of humanity. It follows some general patterns - for example, cultural groupings develop from tribal to national, continental and global. But it also changes over time. In intercultural history, students learn to reflect on the different ways in which people from different groups relate to each other and how this impacts on history.

Table 2: Patterns of sense-making in two dimensions

\begin{tabular}{ll}
\hline $\begin{array}{l}\text { Patterns of temporal sense- } \\
\text { making }\end{array}$ & Patterns of sociological/cultural sense-making \\
\hline $\begin{array}{l}\text { Traditional } \\
\text { Different examples of relationships } \\
\text { between cultures }\end{array}$ & $\begin{array}{l}\text { Anthropological universals; common to all cultures } \\
\text { Different concepts of differentiation and affiliation } \\
\text { according to different groups, for example racial, } \\
\text { ethnic, religious }\end{array}$ \\
$\begin{array}{l}\text { Cultural variation of inherited } \\
\text { genetic characteristics }\end{array}$ & Total individuality \\
\hline
\end{tabular}

\section{The consequences of progression from intercultural to transcultural history education}

Moving on from the two dimensions (societal and temporal), which define intercultural history education, we take our thinking further to define the concept of transcultural history education. Transcultural history is not only learning about, or thinking from, the perspectives of other cultures, but it is about developing the competence to reflect on how one's own culture, and the cultures of others, impact on how people's identities evolve over time. This means understanding that cultures are societal constructs. It neither identifies students as members of a specific group, nor denies them their own cultural affiliations. Instead, it gives them insights into how their own culture and other cultures were constructed over time. This enables them to widen their perspectives. It creates the opportunity to engage with topics that consider differences between people in the past and how this influences the present, and the variety of ways in which people are different. 


\section{Transcultural multiperspectivity}

One way of addressing these challenges for history education is to rethink the widely accepted concept of multiperspectivity in a transculturally sensitive and historically reflective way. This can be done by drawing on a distinction introduced by Klaus Bergmann $(1994,2004)$, who differentiated between three temporal layers of multiperspectivity. The first layer of multiperspectivity is concerned with the differences between people who lived in the past, who therefore experienced that past differently, so that in primary sources we do not only find partial or biased information that could be overcome by extending the documentary base, but also evidence as to the diversity of these past perspectives.

Multiperspectivity in this context encompasses the idea that all human perceptions and evaluations are inescapably subjective. 'Different historical actors have diverse perspectives on the events in which they are involved. Exploring these is key to understanding historical events' (see, for example, Seixas and Morton, 2013: 136, cf. 160ff.).

The second layer of multiperspectivity (controversiality) refers to retrospective accounts of a particular event or complex. This is based on two fundamental insights: first, that the beliefs, values and motivations of one period are different from those of other periods (Seixas and Morton, 2013: 136); and second, that at any time after an event, different people have different perspectives on the past. Controversiality accounts for the fact that while historiographers' accounts might and will differ due to errors, bias and even lies, they also represent different attitudes towards, conceptions of, and interests in, the past.

The third layer of multiperspectivity (plurality) is largely missing in Seixas and Morton's chapter on historical perspectives, but it is covered in their reflections on the ethical dimension. Plurality refers to students (and others) being entitled to a range of different perspectives on the past, and in consequence to a variety of knowledge gained from previous judgements about the past. But to whose past are we referring? Any idea of plurality that claims that each culture (or nation) should concentrate on their own history is misleading. In the light of inter- and transcultural multiperspectivity, all claims to owning a history are weak. The past does not belong to any single person or group. Perspectives must be neither negated nor fixed for a learner. They are not established facts, but subject to reflection and change. Each person present in the classroom or in discussion must be allowed to make and define claims, but should be prompted also to reflect, question and change their own cultural position in the context of the learning process.

The concept of transcultural multiperspectivity does not only apply to present students. It can also refer to reflecting on the cultural concepts and affiliations of past societies. Figure 1 highlights this: the three temporal layers of multiperspectivity are represented along a vertical temporal axis. For each layer, several different perspectives are indicated around a historical topic, which is not confined to the past only, but rather extended along the temporal axis, referring to the distinction between the past and history, and the narrative nature of history. Using this concept, different forms of addressing a historical question in research and teaching can be identified. Figure 2 shows an example of two different ways of addressing a historical topic, which may be relevant in post-traditional societies. 


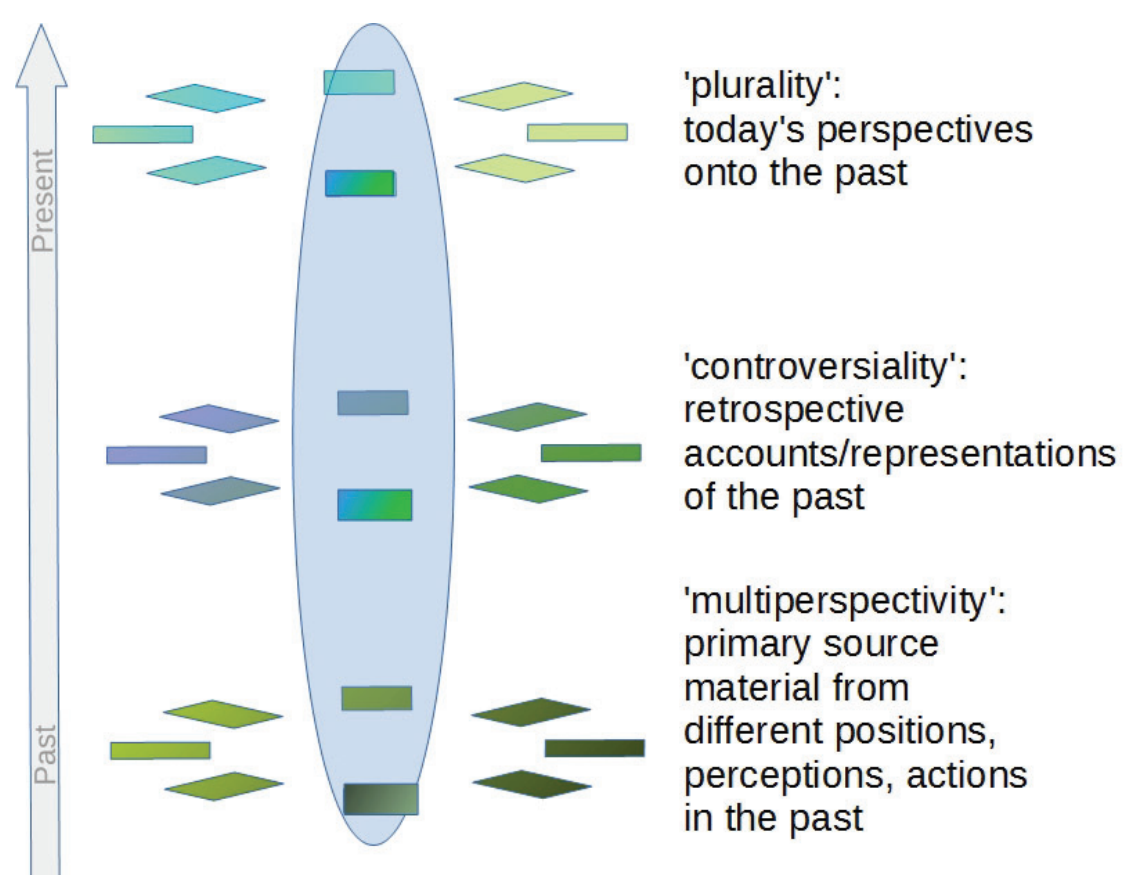

Figure 1: A transcultural model of multiperspectivity

Neither of these orientations can stand alone. It is not a question of either/or, but of reflecting the interplay of a set of cultural dimensions, dividing and joining us at the same time. References to common features and experiences today may not overrule any recognition of ancestors' experiences or deeds as one's 'own'. Neither should identification with one's ancestors hinder recognition of, and reflection on, common features and experiences in an emerging global world characterized by both continuity and change.

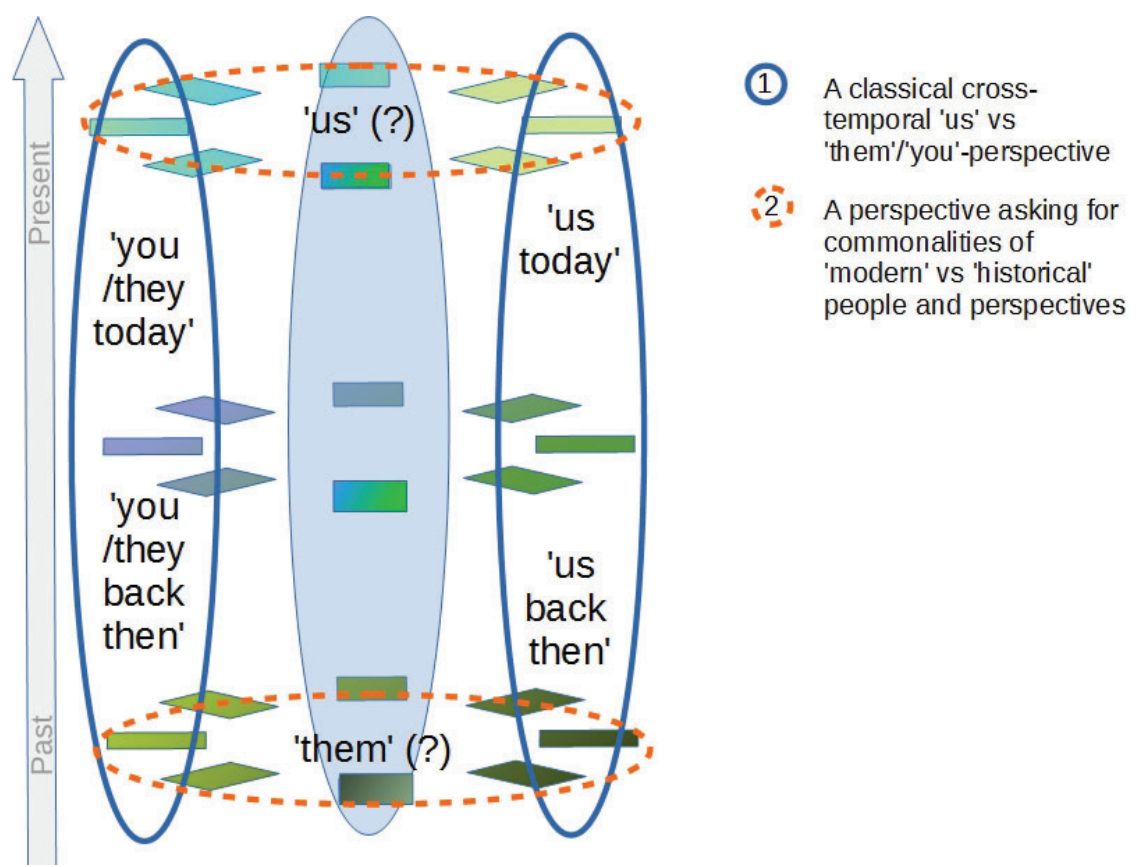

Figure 2: Two different forms of addressing a historical subject 
In Figure 2, the two ovals on the left and right (1) symbolize the view that the perspectives of today are different from those of the past. Such a conception is, for example, discernible in textbook chapters on the Crusades, which juxtapose Frankish and Muslim primary sources with today's Western and Arabic accounts, implying that in each case the Western and the non-Western perspectives were identical and only separated by time. This conceptualization is also apparent in debates about compensation for damages inflicted by Europeans on the societies of their former colonies - seen most clearly in recent claims for restitution and reparation from Germany towards the people of the Herero because of the 1904 genocide and other similar examples (Zimmerer and Zeller, 2008). All these claims rely on the identification of identity across time (in the traditional mode of sense-making).

The orange ovals in Figure 2 (2) represent the view that all references to reconciliation based on a notion that we today have learned from the cruelties of the past entail a notion of commonality across the traditional divide, and at least claim some kind of shared culture. From this perspective, Africans and Europeans today can jointly refer to a modern understanding of human rights, can meet in a retrospective reflection on the experience of slave trading and make common efforts to overcome its effects - for example, through acts of restoration. Within Western societies at least, many citizens cannot easily be identified as descendants of former Europeans only. The same is true, if not to the same extent, for African and Asian societies, and also for Latin America. Therefore, many citizens both of the global North and the global South will not easily fit into the scheme presented in Figure 2 under (1), whereas the question of commonalities of modern versus premodern people may also be too broad. What is needed is the ability to think not in binaries, but to reflect on identities and perspectives in the temporal dimension in more complex forms. The question of historical identity is not one of which group one belongs to, but rather of to what degree, and in what narrative form, one can relate to different traditions. Would it, for example, suffice for a German multi-ethnic student to choose between a family heritage of being from a jurisdiction that was colonized and living in a jurisdiction with a tradition of colonization? Can, and should, an immigrant German acknowledge responsibility and even liability for these pasts? The answer can be neither yes nor no, but instead a narrative reflection on personal identity in the light of these (and other) legacies and histories. And reflecting on one's own tradition will not suffice either. The way others have constructed meaning about the past is also relevant for creating one's own historical identity today.

Inter- and transcultural education may not only aim at the acknowledgement of given traditions and heritage, but also at reflection on different perspectives, experiences and ways of thinking. How, then, can this be furthered by historical thinking in education? Figure 3 exemplifies some didactic opportunities to support inter- and transcultural reflection on perspectives in history education. Transcultural history education should address intercultural encounters and conflicts in the past (A) and use primary source material from different perspectives in the past under study (D)). But it should also address relevant differences between later cultural and/ or social positions in later times (C) as well as in the present (B) with regard to their relevance for historiographical perspectives on the time in question and the resulting interpretations ( $(\mathrm{E})$ and $(\mathrm{F})$. 
The distinction between inter- and transcultural approaches is that the focus of the former is on the different groups as given protagonists and on their relation to today's identities, including that of learners, and the focus of the latter is on the constitution of these identities. While such a reflective focus may not be pressed upon students, questioning their own identities in an inquisitive way, transcultural history education should always give them an opportunity to reflect on their own position, and perspectives, and those of others, as well as their interrelations.

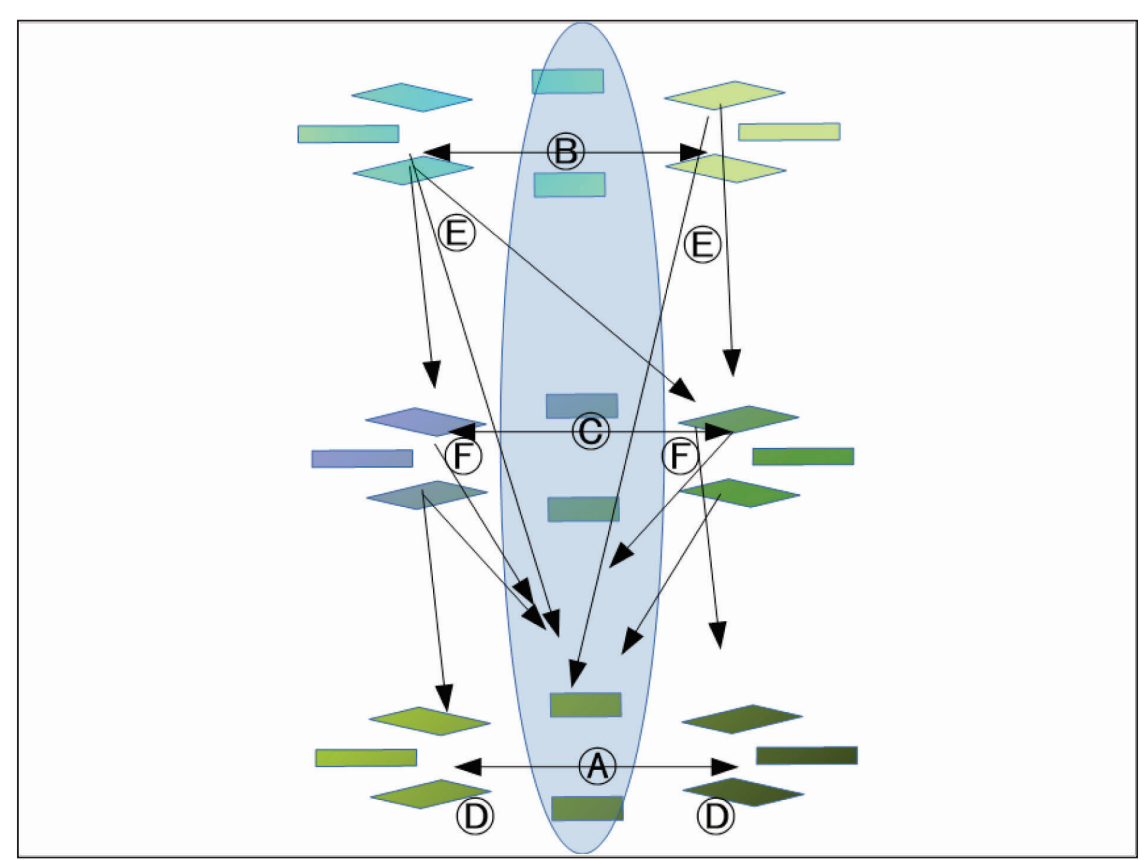

Figure 3: Dimensions of addressing perspective on intercultural topics

\section{Topics of transcultural history education}

What are some possible topics for transcultural history education? Table 3 gives some suggestions on how topics may change in relation to different concepts of cultural history education. It should be noted that such an approach neither requires nor suggests abandoning standard topics of history education, but it does call for a considerable shift in the way they are turned into subjects, mainly by explicitly addressing at last a diversity of positions and perspectives entangled in them and in the present.

In the next section, a far from exhaustive list of possible subjects is suggested, then suggestions are made on what transcultural profiling of traditional subjects might look like. 
Table 3: Consequences of cultural learning concepts for addressing subjects (examples)

\begin{tabular}{|c|c|c|c|c|}
\hline & $\begin{array}{l}\text { Monocultural } \\
\text { history education }\end{array}$ & $\begin{array}{l}\text { Multicultural } \\
\text { history education }\end{array}$ & $\begin{array}{l}\text { Intercultural } \\
\text { history } \\
\text { education }\end{array}$ & $\begin{array}{l}\text { Transcultural } \\
\text { history } \\
\text { education }\end{array}$ \\
\hline $\begin{array}{l}\text { Conflicts } \\
\text { of cultures }\end{array}$ & $\begin{array}{l}\text { - Our war(s) } \\
\text { against our } \\
\text { enemies } \\
\text { - The wars } \\
\text { between x and y } \\
\text { - Colonial history } \\
\text { as wars: } \\
\text { o Representing } \\
\text { it as heroic } \\
\text { versions } \\
\text { o Post-colonial } \\
\text { criticism }\end{array}$ & $\begin{array}{l}\text { - A focus on } \\
\text { peaceful } \\
\text { coexistence of } \\
\text { members of } \\
\text { different cultures } \\
\text { in the light of } \\
\text { overcoming past } \\
\text { hostilities }\end{array}$ & $\begin{array}{l}\text { - What do } \\
\text { earlier conflicts } \\
\text { between } \\
\text { cultures/nations } \\
\text { mean for how } \\
\text { we live together } \\
\text { today? } \\
\text { - How do former } \\
\text { conflicts } \\
\text { between } \\
\text { different } \\
\text { cultures affect } \\
\text { their relations } \\
\text { today, and the } \\
\text { coexistence of } \\
\text { members of } \\
\text { both in today's } \\
\text { societies? }\end{array}$ & $\begin{array}{l}\text { - Mutual images } \\
\text { and self- } \\
\text { descriptions of } \\
\text { parties in wars } \\
\text { - Perspectives } \\
\text { on past wars } \\
\text { in different } \\
\text { societies and } \\
\text { societal sub- } \\
\text { groups today } \\
\text { - Reflecting on } \\
\text { the effects of } \\
\text { knowledge } \\
\text { about one's } \\
\text { forebears' } \\
\text { crimes on one's } \\
\text { identity }\end{array}$ \\
\hline $\begin{array}{l}\text { Contacts } \\
\text { of cultures }\end{array}$ & $\begin{array}{l}\text { - Addressing other } \\
\text { cultures only } \\
\text { when a relation } \\
\text { to one's own } \\
\text { history is evident: } \\
\text { o Our own } \\
\text { worldliness } \\
\text { as developed } \\
\text { by contacting } \\
\text { others; } \\
\text { explorers } \\
\text { o History of } \\
\text { one's own } \\
\text { empire } \\
\text { Colonial } \\
\text { history as } \\
\text { civilizing } \\
\text { efforts }\end{array}$ & $\begin{array}{l}\text { - Fostering } \\
\text { coexistence of } \\
\text { members of } \\
\text { different cultures } \\
\text { by addressing } \\
\text { their respective } \\
\text { contributions } \\
\text { to human } \\
\text { development and } \\
\text { today's societies } \\
\text { - Promoting } \\
\text { acknowledgement } \\
\text { of diversity by } \\
\text { highlighting the } \\
\text { complementary } \\
\text { aspects of } \\
\text { different cultures }\end{array}$ & $\begin{array}{l}\text { - Addressing and } \\
\text { questioning } \\
\text { stereotypes } \\
\text { (positive and } \\
\text { negative ones) } \\
\text { as obstacles for } \\
\text { positive cultural } \\
\text { relations } \\
\text { - Focusing } \\
\text { on positive } \\
\text { examples of } \\
\text { intercultural } \\
\text { relations in the } \\
\text { past }\end{array}$ & $\begin{array}{l}\text { - How can we } \\
\text { understand } \\
\text { being German } \\
\text { after Auschwitz/ } \\
\text { Christian after } \\
\text { the Crusades / } \\
\text { European after } \\
\text { colonial rule } \\
\text { etc.? }\end{array}$ \\
\hline Migration & $\begin{array}{l}\text { - History of } \\
\text { emigration into } \\
\text { foreign countries } \\
\text { - History of } \\
\text { immigration of } \\
\text { different groups }\end{array}$ & $\begin{array}{l}\text { - History of the } \\
\text { development of } \\
\text { coexistence of } \\
\text { different groups }\end{array}$ & $\begin{array}{l}\text { - Examples for } \\
\text { inter-group } \\
\text { relations in the } \\
\text { context of past } \\
\text { migrations } \\
\text { - Comparison of } \\
\text { different forms } \\
\text { of migrations } \\
\text { with regard to } \\
\text { their relevance } \\
\text { for inter-group } \\
\text { relations }\end{array}$ & $\begin{array}{l}\text { - Development } \\
\text { and change } \\
\text { of migrating } \\
\text { groups in } \\
\text { different forms } \\
\text { of migrations } \\
\text { - Concepts of } \\
\text { identification in } \\
\text { post-migration } \\
\text { states }\end{array}$ \\
\hline
\end{tabular}




\begin{tabular}{|c|c|c|c|c|}
\hline & $\begin{array}{l}\text { Monocultural } \\
\text { history education }\end{array}$ & $\begin{array}{l}\text { Multicultural } \\
\text { history education }\end{array}$ & $\begin{array}{l}\text { Intercultural } \\
\text { history } \\
\text { education }\end{array}$ & $\begin{array}{l}\text { Transcultural } \\
\text { history } \\
\text { education }\end{array}$ \\
\hline Minorities & $\begin{array}{l}\text { - Histories of } \\
\text { minorities (the } \\
\text { Germans in ... } \\
\text { the USA, Eastern } \\
\text { Europe, etc.) } \\
\text { - Upholding our } \\
\text { identity on } \\
\text { foreign soil/ } \\
\text { under foreign } \\
\text { rule, etc. }\end{array}$ & $\begin{array}{l}\text { - Patterns of unity in } \\
\text { diversity in Europe } \\
\text { - The Canadian } \\
\text { Quilt of Belonging } \\
\text { approach (Bryan } \\
\text { 2005) }\end{array}$ & $\begin{array}{l}\text { - Majority- } \\
\text { minority } \\
\text { relations } \\
\text { in different } \\
\text { historical } \\
\text { settings } \\
\text { - Melting-pots, } \\
\text { salad bowl, } \\
\text { The Habsburg } \\
\text { Empire - prison } \\
\text { of nations? } \\
\text { - Patterns of } \\
\text { exclusion and } \\
\text { inclusion of } \\
\text { minorities }\end{array}$ & $\begin{array}{l}\text { - The emergence } \\
\text { of national } \\
\text { identities }\end{array}$ \\
\hline $\begin{array}{l}\text { Development } \\
\text { of cultural } \\
\text { identities }\end{array}$ & $\begin{array}{l}\text { - History of our } \\
\text { becoming a } \\
\text { nation }\end{array}$ & & & $\begin{array}{l}\text { - Construction } \\
\text { of identities via } \\
\text { presentations } \\
\text { of history, for } \\
\text { example in } \\
\text { exhibitions }\end{array}$ \\
\hline
\end{tabular}

\section{Possible transcultural enquiries and reflections for history education}

Students might explore how common and different experiences of colonialism relate to differences and commonalities today. In relation to this, they might consider the perspectives represented in shared and different traditions and customs. They might investigate and reflect on the ways in which our different conceptions of 'us' and 'them' today (for example, conceptions of race, religion, culture, Western versus nonWestern) depend on concepts and structures developed in past times. They might reflect on what is binding and what is not binding in cultural (and other) traditions in order to establish one's identity - especially when confronted with analyses of sensitive and problematic pasts, such as reflecting on whether, or based on what reasoning, Germans can claim Goethe, Schiller and Beethoven as part of their own culture while avoiding, for example, Himmler and Heydrich (Barricelli, 2005).

Students might discuss and reflect on possible or necessary transformations of national and/or cultural identities in the light of crimes (and even genocides) of forebears, for example, by discussing how Germans today can understand their being German differently, in the light not only of the Holocaust, but also of colonialism, for example the Herero genocide. Is it possible to defend a positive notion of German identity against this experience, to reject it altogether in favour of non-national identities, or to develop a reflective form, acknowledging this negative past and addressing consequences? By the same logic, Christians today have to make up their minds on whether they can still be Christians after the Crusades, and how they can come to terms with this (cf. Körber, 2017a). Similarly, students need to consider the relevance of the crimes and heroic deeds of others for their own humanity, too. Rather than relating to them using categories of us and them, it must be considered in what way, and to what degree, the lessons from the Holocaust are mainly national, and to what degree they present universal measures for humanistic and universalist identification. 
Furthermore, students should consider and reflect on different conceptions of what a common future might, may or should look like, and how these different conceptions, expectations and possibilities draw on different stories about shared and divided histories. As for colonialism, it is necessary to address it neither as one single, comprehensive story, nor as separate stories depending on the perspectives of former colonizers versus the colonized, but to address complex entanglements of both commonalities and differences. It is not only immigrants to Europe from former colonized regions who have to reflect on both their connections with the oppressed and the oppressors; all learners have to develop reflective narratives on these topics and legacies.

\section{Conclusion}

Using these conceptual frameworks, history education could overcome its traditional task of ensuring that students assimilate the content and values of a specific culture and develop a collective identity, underpinning assumptions of common descent, common fate and claims of affiliation and allegiance with master narratives of their own pride and pain (van der Leeuw-Roord, 1996). In 1990, an attempt was made to ensure that this grand narrative approach was not repeated at a European level by publishing a common European textbook (Aldebert, 1993; Delouche, 1993, 2012; for a critique, see van der Leeuw-Roord, 1996, 2008). But, however honourable the aims of fostering a common European identity are - especially in the light of the current crisis of the European Union and Brexit - the mere repetition of nation-building - by other means - will not be solved by history. At best, this will simply postpone the problems created by non-reflective identities. At worst, it will aggravate them in the light of increased immigration. Nevertheless, there are still a lot of problems to overcome. How can history education deal with the insight that all these reflections are deeply rooted in a largely Western form of thinking, both about culture and about history? To what degree can we project a path to a more reflective form of history teaching, if we rely on concepts of individualism and critical thinking? Yet, how could we sacrifice them? Surely, concepts of recognizing and accepting different views and interests may help, but then non-national perspectives, such as migratory identities, will have to be accepted and reflected as are cultural ones. It is to be hoped that a reflective stance towards the conceptual framework of inter- and transculturalism will help.

\section{Notes on the contributor}

Dr Andreas Körber is a professor of education with a special focus on history and political education at Hamburg University. His research interests include historical consciousness, competences of historical thinking, assessment of historical competences, memory culture and memorial education, and intercultural and inclusive history education.

\section{References}

Alavi, B. (1998) Geschichtsunterricht in der multiethnischen Gesellschaft: Eine fachdidaktische Studie zur Modifikation des Geschichtsunterrichts aufgrund migrationsbedingter Veränderungen. Frankfurt am Main: IKO - Verlag für Interkulturelle Kommunikation.

Alavi, B. and Lücke, M. (eds) (2016) Geschichtsunterricht ohne Verlierer!? Inklusion als Herausforderung für die Geschichtsdidaktik. Schwalbach am Taunus: Wochenschau Verlag. 
Aldebert, J. (1993) Das Europäisches Geschichtsbuch: Geschichtliches Unterrichtswerk für die Sekundarstufe I und II. Stuttgart: Klett.

Barricelli, M. (2005) 'Beobachtungen zu aktuellen Artikulationsformen jugendlichen Geschichtsbewußtseins im Zeichen popkultureller Erneuerung der Nation'. Handlung Kultur Interpretation: Zeitschrift für Sozial- und Kulturwissenschaften, 2, 228-74.

Barricelli, M., Gautschi, P. and Körber, A. (2012) 'Historische Kompetenzen und Kompetenzmodelle'. In Barricelli, M. and Lücke, M. (eds) Handbuch Praxis des Geschichtsunterrichts: Historisches Lernen in der Schule. Schwalbach am Taunus: Wochenschau Verlag, 207-35.

Becher, U.A.J. (1985) 'Der geschichtliche Standort von Friedrich J. Lucas'. In Lucas, F.J. Geschichte als engagierte Wissenschaft: Zur Theorie einer Geschichtsdidaktik. Ed. Becher, U.A.J. Stuttgart: Klett, 7-15.

Bergmann, K. (1994) 'Multiperspektivität'. Geschichte in Wissenschaft und Unterricht, 45, 194-8.

Bergmann, K. (2004) 'Multiperspektivität'. In Mayer, U., Pandel, H.-J. and Schneider, G. (eds) Handbuch Methoden im Geschichtsunterricht. Schwalbach am Taunus: Wochenschau Verlag, 65-77.

Bormuth, H., Körber, A., Seidl, P. and Witt, D. (forthcoming, 2019) 'Inklusive Diagnostik: Ein Werkzeug zur Planung inklusiven (Geschichts-)Unterrichts'. In Alavi, B., Barsch, S., Kühberger, C. and Lücke, M. (eds) Handbuch Diversität im Geschichtsunterricht. Zugänge einer inklusiven Geschichtsdidaktik. Frankfurt am Main: Wochenschau Verlag.

Bryan, E. (2005) Quilt of Belonging: The Invitation Project. Erin, ON: Boston Mills Press.

Delouche, F. (ed.) (1993) Illustrated History of Europe: A unique guide to Europe's common heritage. London: Weidenfeld and Nicolson.

Delouche, F. (ed.) (2012) Das europäische Geschichtsbuch: Von den Anfängen bis ins 21. Jahrhundert. 2nd ed. Stuttgart: Klett-Cotta.

Georgi, V.B. (2003) Entliehene Erinnerung: Geschichtsbilder junger Migranten in Deutschland. Hamburg: Hamburger Edition.

Georgi, V.B. and Ohliger, R. (eds) (2009) Crossover Geschichte: Historisches Bewusstsein Jugendlicher in der Einwanderungsgesellschaft. Hamburg: Edition Körber-Stiftung.

Hasberg, W. (2002) 'Siegfried Kawerau (1886-1936)'. In Fröhlich, M. (ed.) Die Weimarer Republik: Portrait einer Epoche in Biographien. Darmstadt: Wissenschaftliche Buchgesellschaft, 293-304.

Höhne, T., Kunz, T. and Radtke, F.-O. (eds) (1999) Bilder von Fremden. Formen der Migrantendarstellung als der 'anderen Kultur' in Deutschen Schulbüchern von 1981-1997. Frankfurt am Main: Johann Wolfgang Gothe Universitat.

Jeismann, K.-E. (1977) 'Didaktik der Geschichte: Die Wissenschaft von Zustand, Funktion und Veränderung geschichtlicher Vorstellungen im Selbstverständnis der Gegenwart'. In Kosthorst, E. and Jeismann, K.-E. (eds) Geschichtswissenschaft: Didaktik, Forschung, Theorie. Göttingen: Vandenhoeck und Ruprecht, 9-33.

Kawerau, S. (1924) Alter und neuer Geschichtsunterricht. Leipzig: Oldenburg.

Körber, A. (ed.) (2001a) Interkulturelles Geschichtslernen: Geschichtsunterricht unter den Bedingungen von Einwanderung und Globalisierung; konzeptionelle Überlegungen und praktische Ansätze. Münster: Waxmann.

Körber, A. (2001b) 'Interkulturelles Lernen im Geschichtsunterricht - eine Einleitung'. In Körber, A. (ed.) Interkulturelles Geschichtslernen: Geschichtsunterricht unter den Bedingungen von Einwanderung und Globalisierung; konzeptionelle Überlegungen und praktische Ansätze. Münster: Waxmann, 5-26.

Körber, A. (2010) 'Theoretische Dimensionen des interkulturellen Geschichtslernens'. In Ventzke, M., Mebus, S. and Schreiber, W. (eds) Geschichte denken statt pauken in der Sekundarstufe II: 20 Jahre nach der friedlichen Revolution: Deutsche und europäische Perspektiven im gymnasialen Geschichtsunterricht. Radebeul: Sächsisches Bildungsinstitut, 25-48.

Körber, A. (2015) Historical Consciousness, Historical Competencies - and Beyond? Some conceptual development within German history didactics. Frankfurt am Main: Deutsches Institut für Internationale Pädagogische Forschung. Online. www.pedocs.de/volltexte/2015/10811/pdf/ Koerber_2015_Development_German_History_Didactics.pdf (accessed 22 February 2018).

Körber, A. (2017a) 'Historical consciousness and the moral dimension'. Historical Encounters: A Journal of Historical Consciousness, Historical Cultures, and History Education, 4 (1), 81-9.

Körber, A. (2017b) 'Intercultural Learning in History Education (2001)'. Abridged translation. Online. www.pedocs.de/volltexte/2017/12905/pdf/Koerber_2017_Intercultural_Learning_in_History_ Education.pdf (accessed 22 February 2018). 
Körber, A. (forthcoming, 2019) 'Inklusive Geschichtskultur: Bestimmungsfaktoren und Ansprüche'. In Alavi, B., Barsch, S., Kühberger, C. and Lücke, M. (eds) Handbuch Diversität im Geschichtsunterricht. Zugänge einer inklusiven Geschichtsdidaktik. Frankfurt am Main: Wochenschau Verlag.

Körber, A. and Meyer-Hamme, J. (2008) 'Interkulturelle historische Kompetenz? Zum Verhältnis von Interkulturalität und Kompetenzorientierung beim Geschichtslernen'. In Bauer, J.-P., Meyer-Hamme, J. and Körber, A. (eds) Geschichtslernen - Innovationen und Reflexionen: Geschichtsdidaktik im Spannungsfeld von theoretischen Zuspitzungen, empirischen Erkundungen, normativen Überlegungen und pragmatischen Wendungen: Festschrift für Bodo von Borries zum 65. Geburtstag. Kenzingen: Centaurus Verlag, 307-34.

Körber, A., Schreiber, W. and Schöner, A. (eds) (2007) Kompetenzen historischen Denkens: Ein Strukturmodell als Beitrag zur Kompetenzorientierung in der Geschichtsdidaktik. Neuried: ars una.

Körber, A., Seidl, P., Witt, D. and Bormuth, H. (forthcoming, 2019) 'Inklusives Geschichtslernen via Scaffolding von Aufgaben'. In Alavi, B., Barsch, S., Kühberger, C. and Lücke, M. (eds) Handbuch Diversität im Geschichtsunterricht. Zugänge einer inklusiven Geschichtsdidaktik. Frankfurt am Main: Wochenschau Verlag.

Lucas, F.J. (1985) Geschichte als engagierte Wissenschaft: Zur Theorie einer Geschichtsdidaktik. Ed. Becher, U.A.J. Stuttgart: Klett.

Meyer-Hamme, J. (2009) Historische Identitäten und Geschichtsunterricht: Fallstudien zum Verhältnis von kultureller Zugehörigkeit, schulischen Anforderungen und individueller Verarbeitung. Idstein: Schulz-Kirchner.

Nohl, A.-M. (2010) Konzepte interkultureller Pädagogik: Eine systematische Einführung. 2nd ed. Bad Heilbrunn: Klinkhardt.

Rathje, S. (2006) 'Interkulturelle Kompetenz: Zustand und Zukunft eines umstrittenen Konzepts'. Zeitschrift für Interkulturellen Fremdsprachenunterricht, 11 (3), 1-21. Online. http://tujournals.ulb. tu-darmstadt.de/index.php/zif/article/view/396/384 (accessed 15 July 2018).

Rathje, S. (2007) 'Intercultural competence: The status and future of a controversial concept'. Language and Intercultural Communication, 7 (4), 254-66.

Ruchniewicz, K. (2005) 'Der Entstehungsprozess der Gemeinsamen deutsch-polnischen Schulbuchkommission 1937/38-1972'. Archiv für Sozialgeschichte, 45, 237-52.

Rüsen, J. (1983) Historische Vernunft: Grundzüge einer Historik I: Die Grundlagen der Geschichtswissenschaft. Göttingen: Vandenhoeck und Ruprecht.

Rüsen, J. (2005) History: Narration, interpretation, orientation. New York: Berghahn Books.

Schörken, R. (1980) 'Geschichtsunterricht in der kleiner werdenden Welt: Prolegomena zu einer Didaktik des Fremdverstehens'. In Süssmuth, H. (ed.) Geschichtsdidaktische Positionen: Bestandsaufnahme und Neuorientierung. Paderborn: Schöningh, 315-35.

Seixas, P. and Morton, T. (2013) The Big Six Historical Thinking Concepts. Toronto: Nelson Education.

Thomas, A. (1993) 'Psychologie interkulturellen Lernens und Handelns'. In Thomas, A. (ed.) Kulturvergleichende Psychologie: Eine Einführung. Göttingen: Hogrefe Verlag für Psychologie, 377-424.

Tiemann, D. (1979) 'Auch ein Forum deutsch-französischer Kommunikation - Georg Eckert-Institut für internationale Schulbuchforschung'. Dokumente: Zeitschrift für den deutsch-französischen Dialog, 35, 293-302.

Ulich, M. (2000) 'Interkulturelle Kompetenz - Erziehungsziele und pädagogischen Alltag'. Archiv frühe Kindheit, Ausgabe 1. Online. http://liga-kind.de/fk-100-ulich/ (accessed 15 July 2018).

Ullrich, M. (2016) 'Multi? Inter? Trans! Plädoyer für ein transkulturelles historisches Lernen unter rassismuskritischer Perspektive'. In Brüning, C., Deile, L. and Lücke, M. (eds) Historisches Lernen als Rassismuskritik. Schwalbach am Taunus: Wochenschau Verlag, 163-84.

van der Leeuw-Roord, J. (1996) 'Could the "History of Europe" avoid the traditional European mirror of pride and pain? The comparison of two different versions of Frédéric Delouche "History of Europe"'. Internationale Schulbuchforschung: Zeitschrift des Georg-Eckert-Instituts für Internationale Schulbuchforschung, 18, 85-106.

van der Leeuw-Roord, J. (2008) 'A common textbook for Europe? Utopia or a crucial challenge'. In Bauer, J.-P., Meyer-Hamme, J. and Körber, A. (eds) Geschichtslernen - Innovationen und Reflexionen: Geschichtsdidaktik im Spannungsfeld von theoretischen Zuspitzungen, empirischen Erkundungen, normativen Überlegungen und pragmatischen Wendungen: Festschrift für Bodo von Borries zum 65. Geburtstag. Kenzingen: Centaurus Verlag, 43-59. 
von Borries, B. (2001) 'Interkulturalität beim historisch-politischen Lernen - Ja sicher, aber wie?'. In Körber, A. (ed.) Interkulturelles Geschichtslernen: Geschichtsunterricht unter den Bedingungen von Einwanderung und Globalisierung; konzeptionelle Überlegungen und praktische Ansätze. Münster: Waxmann, 73-96.

Welsch, W. (1999) 'Transculturality: The puzzling form of cultures today'. In Featherstone, M. and Lash, S. (eds) Spaces of Culture: City, nation, world. London: SAGE Publications, 194-213.

Zimmerer, J. and Zeller, J. (eds) (2008) Genocide in German South-West Africa: The Colonial War of 1904-1908 and its aftermath. Monmouth: Merlin Press. 